\title{
Ovarian blood flow in compensatory hypertrophy in the rat
}

\author{
B. Varga, Katalin Csiszár and E. Stark \\ Institute of Experimental Medicine, Hungarian Academy of Sciences, \\ 1450-Budapest, P.O. Box 67, Hungary
}

Unilateral ovariectomy is followed by compensatory hypertrophy of the contralateral ovary in the rat (Carmichael \& Marshall, 1908; Arai, 1920; Slonaker, 1927). This phenomenon is induced by the increased gonadotrophic hormone release resulting from the decrease of the oestrogen level via a negative feedback mechanism (Heller, Heller \& Sevringhaus, 1942; Edgren, Parlow, Peterson \& Jones, 1965; Johnson, 1966; Peppler \& Greenwald, 1970). After hemiovariectomy the contralateral ovary produces the same number of ova as did both ovaries in the control animals (Peppler, 1972). Of the gonadotrophic hormones, LH increases ovarian blood flow and, since ovarian blood flow is known to increase during oestrus (Wurtman, 1964), the present study was to determine whether the elevated gonadotrophic hormone level resulting from hemiovariectomy increased blood flow in the remaining ovary.

Rats of the CFY strain and weighing $170-200 \mathrm{~g}$ were randomly allocated to two groups. Under ether anaesthesia, those in Group I were ovariectomized on the left side, and those in Group II were subjected to laparotomy only. On Days 6,12 and 18 after hemiovariectomy, the animals were anaesthetized with $35 \mathrm{mg}$ sodium pentobarbitone (May and Baker Ltd, England)/kg body wt, and $5 \mu \mathrm{Ci}{ }^{86} \mathrm{RbCl}$ were injected by a thin needle into the jugular vein. The ${ }^{86} \mathrm{Rb}$ method of Sapiristein (1958) was applied to determine the ovarian fraction of cardiac output. This method is useful and accurate to measure blood flow to the ovary (Setchell \& Linzell, 1974), but it may underestimate blood flow to the CL in sheep (Brown, Hales \& Mattner, 1974) as compared to microsphere techniques. At $30 \mathrm{sec}$ after the injection, $0.3 \mathrm{ml} 1 \%$ Evans blue solution was injected by the same route to determine cardiac output (Hamilton, Moore, Kimsman \& Spurling, 1932). Blood pressure was checked in the femoral artery with a Statham's pressure transducer. The animals were killed by an i.v. injection of a supersaturated $\mathrm{KCl}$ solution. The ovary was removed, cleaned, weighed and dissolved in sodium hydroxide. Radioactivity was measured with a Packard Tri-Carb scintillation spectrometer. Analysis of variance was used for statistical evaluation (Scheffé, 1959).

There were no differences in the body weights and blood pressure values of the ovariectomized and control rats. After left hemiovariectomy, the weight of the right ovary significantly increased $(P<0.01)$, the increase being most marked on Day 12 (Table 1). However, the fraction of cardiac output and the blood flow of the hypertrophic ovary did not differ from those of the controls (Table 1).

Table 1. The effect of left hemiovariectomy or laparotomy only on the mean ( \pm S.E.M.) weight of the right ovary, fractional perfusion and ovarian blood flow of rats (nos in parentheses)

\begin{tabular}{lccc}
\hline & $\begin{array}{c}\text { Ovarian wt } \\
(\mathrm{mg} / 100 \mathrm{~g} \text { body wt) }\end{array}$ & $\begin{array}{c}\text { Cardiac output } \\
(\% / \mathrm{g} \text { ovarian wt) }\end{array}$ & $\begin{array}{c}\text { Ovarian blood flow } \\
(\mathrm{ml} / \mathrm{min} / \mathrm{g})\end{array}$ \\
\hline $\begin{array}{l}\text { Control rats } \\
\text { Day 6 }\end{array}$ & $20.5 \pm 1.49(14)$ & $1.386 \pm 0.059(12)$ & $0.813 \pm 0.061(9)$ \\
Day 12 & $21.8 \pm 0.99(12)$ & $1.363 \pm 0.110(12)$ & $1.000 \pm 0.174(8)$ \\
Day 18 & $20.7 \pm 1.22(13)$ & $1.654 \pm 0.206(13)$ & $0.988 \pm 0.117(9)$ \\
Hemiovariectomized rats & $25.3 \pm 1.23\left(12^{*}\right)$ & $1.275 \pm 0.060(10)$ & $0.777 \pm 0.036(7)$ \\
Day 6 & $32.6 \pm 1.12\left(14^{*}\right)$ & $1.237 \pm 0.086(13)$ & $0.832 \pm 0.094(12)$ \\
Day 12 & $27.9 \pm 1.25\left(12^{*}\right)$ & $1.488 \pm 0.114(12)$ & $1.004 \pm 0.083(10)$ \\
\hline
\end{tabular}

* Significant difference between control and hemiovariectomized rats, $P<0.01$. 
Our results show that following hemiovariectomy the blood supply of the contralateral ovary expands in proportion to hypertrophy and increases only to the extent necessary to reach the control level of blood flow/unit weight calculated for the organ. The specific increase of blood flow does not appear to be necessary for maintaining hypertrophy and increased ovulation, and indicates that the elevated gonadotrophic hormone level found after hemiovariectomy (Heller et al., 1942: Edgren et al., 1965; Johnson, 1966; Peppler \& Greenwald, 1970) does not affect the blood supply of the surviving ovary. Our data do not, however, preclude the possibility of changes in ovarian blood flow immediately after hemiovariectomy that might be correlated with the increased production of gonadotrophic hormones as a general circulatory reaction to 'surgical trauma'. Wurtman (1964) was unable to obtain an increase in ovarian blood flow in rats by giving FSH, and LH was only effective if given in high doses. In anoestrous dogs both LH and FSH proved to be ineffective (Stark \& Varga, 1968). Our results seem to support the suggestion that unilateral ovariectomy increases only the FSH level in peripheral blood and fails to increase the LH concentration (Benson, Sorrentino \& Evans, 1969; Howland, Jack \& Beaton, 1974).

\section{References}

AraI, H. (1920) On the cause of the hypertrophy of the surviving ovary after semispaying (Albino rat) and on the number of ova in it. Am.J. Anat. 28, 59-79.

Benson, B., Sorrentino, S. \& Evans, J.S. (1969) Increase in serum FSH following unilateral ovariectomy in the rat. Endocrinology 84, 369-374.

Brown, B.W., Hales, J.R.S. \& MatTNER, P.E. (1974) Capillary blood flow in sheep ovaries, measured by iodoantipyrine and microsphere techniques. $E x$ perientia 30, 914-915.

Carmichael, E.S. \& Marshall, F.H.A. (1908) On the occurrence of compensatory hypertrophy in the ovary. J. Physiol., Lond. 36, 431-434.

Edgren, R.A., Parlow, A.F., Peterson, D.L. \& JoNES, R.C. (1965) On the mechanism of ovarian hypertrophy following hemi-castration in rats. Endocrinology 76, 97-102.

Hamilton, W.F., MoORE, J.W., Kimsman, J.M. \& SPURLING, R.G. (1932) Studies on circulation. IV. Further analysis of the injection method and of changes in the hemodynamics under physiological and pathological conditions. Am. J. Physiol. 99, 534-551.

Heller, C.G., Heller, C.J. \& Sevringhaus, E.L. (1942) Does estrogen substitution materially inhibit pituitary gonadotrophin potency? Endocrinology 30, 309-316.

Howland, B.E., JACK, M.I. \& Beaton, D.B. (1974) Effect of hemiovariectomy and strain of rat on serum gonadotrophin levels. Experientia 30, 653-654.
Jornson, D.C. (1966) The use of non-castrate parabiotic rats for the evaluation of plasma gonadotrophins. Acta endocr., Copenh. 51, 269-280.

Peprler, R.D. (1972) Inhibitory effect of hysterectomy on compensatory ovulation in the unilaterally ovarjectomized rats. Am. J. Anat. 135, 299-303.

Peppler, R.D. \& Grenwald, G.S. (1970) Effect of unilateral ovariectomy on ovulation and cycle length in 4- and 5-day cycling rats. Am.J. Anat. 127, $1-7$.

SApIRStein, L.A. (1958) Regional blood flow by fractional distribution of indicators. Am.J. Physiol. 193, 161.

SCHEFE', H. (1959) The Analysis of Variance. John Wiley and Sons Inc. New York.

Setchell, B.P. \& LiNZELL, J.L. (1974) Soluble indicator techniques for tissue blood flow measurement using ${ }^{86} \mathrm{Rb}$-rubidium chloride, urea, antipyrine(phenazone) derivates or $\left[{ }^{3} \mathrm{H}\right]$ water. Clin. exp. Pharmacol. Physiol., Suppl. 1, 15-29.

Slonaker, J.R. (1927) Semi-ovariectomy compensatory hypertrophy of the remaining ovary and migration of ova in the albino rat. Am. J. Physiol. 81, 620-627.

STARK, E. \& VARGA, B. (1968) Effect of ACTH on targetorgan blood flow with special reference to an extra. adrenal effect. Acta med. Acad. sci. Hung. 25, 367381.

WURTMAN, R.J. (1964) An effect of luteinizing hormone on the fractional perfusion of the rat ovary. Endocrinology 75, 927-933.

Received 21 May 1975 